\title{
Selection of strawberry cultivars with tolerance to Tetranychus urticae (Acari: Tetranychidae) and high yield under different managements
}

\author{
A.F. Costa ${ }^{1}$, P.E. Teodoro ${ }^{2}$, L.L. Bhering ${ }^{2}$, M.J. Fornazier ${ }^{1}$, J.S. Andrade ${ }^{1}$, \\ D.S. Martins ${ }^{1}$ and J.S. Zanuncio Junior ${ }^{1}$ \\ ${ }^{1}$ Instituto Capixaba de Pesquisa, Assistência Técnica e Extensão Rural, \\ Venda Nova do Imigrante, ES, Brasil \\ ${ }^{2}$ Laboratório de Biometria, Departamento de Biologia Geral, \\ Universidade Federal de Viçosa, Viçosa, MG, Brasil \\ Corresponding author: P.E. Teodoro \\ E-mail: eduteodoro@hotmail.com
}

Genet. Mol. Res. 16 (2): gmr16029599

Received January 10, 2017

Accepted March 14, 2017

Published April 28, 2017

DOI http://dx.doi.org/10.4238/gmr16029599

Copyright $(2017$ The Authors. This is an open-access article distributed under the terms of the Creative Commons Attribution ShareAlike (CC BY-SA) 4.0 License.

\begin{abstract}
Tetranychus urticae Koch (Acari: Tetranychidae) is considered the main pest of strawberry. Several factors can favor its development, among them the genotype susceptibility and cropping system. The aims of this study were to evaluate the agronomic performance of strawberry cultivars under different managements and to identify strawberry cultivars that meet tolerance to T. urticae and high fruit yield. Thirteen cultivars of strawberry ('Albion', 'Aleluia', 'Aromas', 'Camarosa', 'Camino Real', 'Campinas', 'Diamante', 'Dover', 'Festival', 'Seascape', 'Toyonoka', 'Tudla', and 'Ventana') under three managements (open field, low tunnel, and high tunnel) were evaluated. The T. urticae attack to different cultivars was influenced by managements, being low tunnel the one that provided higher infestations in the most evaluated cultivars. 'Camarosa' was the cultivar with the lower incidence of pest and 'Dover' had the higher infestation.
\end{abstract}

Genetics and Molecular Research 16 (2): gmr16029599 
The genotype most suitable for growing under different managements is the 'Festival' genotype, since it meets tolerance to T. urticae, high fruit yield, and phenotypic stability.

Key words: Fragaria $\mathrm{x}$ ananassa; Genotype $\mathrm{x}$ management interaction; Plant breeding

\section{INTRODUCTION}

Strawberry (Fragaria x ananassa Duch.) is a fruit of great economic importance, being the most popular, cultivated and consumed in the small fruit group (Tazzo et al., 2015). Its cultivation has important socio-economic role in Brazil's agricultural sector due to the increase of income in small properties and fixing workers in rural areas (Costa et al., 2015).

In subtropical regions as in Brazil, it is mainly cultivated during the winter and spring period, predominantly under open-field conditions. However, the area with protected cultivation in tunnels has increased, mainly to minimize the effects of environmental climatic factors, such as rainfall and high humidity, and to reduce the incidence of diseases (Xiao et al., 2001; Ozdemir, 2003; Ozdemir and Gunduz, 2004). Two types of tunnels have been most used in this crop: low tunnel, where the beds are protected individually and high tunnel with cultivation of several beds (Oliveira et al., 2008; Antunes and Peres, 2013). However, if the tunnels are not managed properly they may lead to increases in the mite population Tetranychus urticae (TSSM) Koch (Acari: Tetranychidae) (Svensson, 2006).

TSSM is polyphagous mite species and important pest of agricultural and ornamental crops in the world (Greco et al., 2005). It is one of the most important pests in Brazilian strawberry (Iwassaki et al., 2015) and its control is based on the use of chemicals (Sato et al., 2002; Fadini et al., 2004). Its damages are caused by the mobile forms that cause the appearance of chlorotic points on the upper face of the leaves, which develop into yellowish spots until completely reddish leaves. New leaves may be infested and this depends on the pest infestation; however, their occurrence is greater in older leaves and close to the plastic cover of the beds, especially in longer dry periods. Higher temperatures are favored by the heat emanating from the plastic mulching and can shorten the TSSM cycle (Fornazier and Pratissoli, 2006).

High TSSM infestations in strawberry fields reduce the photosynthetic rate of this plant and are easily noticeable by the formation of webs (Fadini et al., 2004; Bernardi et al., 2015). Irrigation localized by dripping under plastic mulching provides a drier environment and favors the population development of this pest (Fornazier and Pratissoli, 2006). Using protected cultivation environment has also been reported as favorable for the development of TSSM in tomato crop (Maruyama et al., 2002).

Thus, using cultivars less susceptible to TSSM and with high productivity has been demanded, mainly in organic cultivation and without agrochemical systems (Lourenção et al., 2000; Fadini et al., 2004). Therefore, it is important to identify strawberry cultivars that are less susceptible to TSSM and high productivity, regardless of the management used. One way to identify these genotypes is to use adaptability and stability analyses as an auxiliary tool to investigate genotype $\mathrm{x}$ management $(\mathrm{GxM})$ interaction. Thus, this aimed to evaluate the agronomic performance of strawberry cultivars under different managements and to identify strawberry cultivars that meet less susceptibility to TSSM and high fruit yield.

Genetics and Molecular Research 16 (2): gmr16029599 


\section{MATERIAL AND METHODS}

Trial was conducted under field conditions at Centro Regional de Desenvolvimento Rural Centro Serrano of Instituto Capixaba for Technical Assistance and Rural Extension (Incaper), Domingos Martins, highlands of Espírito Santo State (latitude: $20^{\circ} 22^{\prime} 201^{\prime \prime S}$ and longitude $41^{\circ} 03^{\prime} 760^{\prime \prime} \mathrm{W}$; and $950 \mathrm{~m}$ in altitude). The strawberry cultivars Albion, Aleluia, Aromas, Camarosa, Camino Real, Campinas, Diamante, Dover, Festival, Seascape, Toyonoka, Tudla, and Ventana were evaluated. Three managements were evaluated: open field (without plastic cover), low tunnel (milky-colored plastic cover, 75 microns, suspended on galvanized iron arches at approximately $1.0 \mathrm{~m}$ of hight), and high tunnel milky-colored plastic cover, 100 microns, suspended on galvanized iron arches with approximately $2.5 \mathrm{~m}$ of height) in the month of October (spring). The trial was conducted in a randomized complete block design, three replications and 15 plants per plot, spacing $40 \times 40 \mathrm{~cm}$, in three rows, on beds of $30 \mathrm{~cm}$ high and black mulching.

Drip irrigation was used and fertigation was carried out according to the soil analysis. Natural infestation of the TSSM occurred from the trial implantation and was evaluated using a non-destructive method, counting the total number of mites per $\mathrm{cm}^{2}$ (NTSSM) on a leaf (trifoliate) per plant and five plants per plot and using manual lens with 20 -fold increase. After 120 days, infestation was homogeneously controlled in all treatments to standardize the mite effect on production traits and the yield and adaptability of the cultivars to the study region were evaluated. The other agronomic traits evaluated were: total number of fruits (TNF) per plot, number of commercial fruits per plot (NCF), and fruit yield ( $\mathrm{t} / \mathrm{ha})$, which was measured in each plot with $2.4 \mathrm{~m}^{2}$ and extrapolated to 1 ha considering a useful area of $7500 \mathrm{~m}^{2} / \mathrm{ha}$.

Initially, the count data (NTSSM, TNF, and NCF) were transformed into $[\sqrt{ }(\mathrm{x}+1 / 2)]$ and subjected to the Lilliefors and Bartllet tests. For each management, individual analyses of variance were performed according to the following statistical model (Equation 1):

$$
Y_{i j}=\mu+B_{j}+G_{i}+\varepsilon_{i j}
$$

(Equation 1)

where $Y_{i j}$ is the value observed in the $\mathrm{i}$-th genotype evaluated in the $\mathrm{j}$-th repetition; $\mu$ is the overall mean; $B_{j}$ is the $j$-th block effect; $G_{i}$ is the $i$-th genotype considered as fixed; $e_{i j}$ is the random error associated with $\mathrm{Y}_{\mathrm{ij}}$ observation.

After checking that the relationship between the largest and smallest mean squared error of each management was less than seven, we performed the joint analysis of variance according to the following statistical model (Equation 2):

$$
Y_{i j k}=\mu+B / M_{j k}+G_{i}+M_{j}+G M_{i j}+\varepsilon_{i j k}
$$

(Equation 2)

where $\mathrm{Y}_{\mathrm{ijk}}$ is the value observed in the $\mathrm{i}$-th genotype evaluated in the $\mathrm{j}$-th management in the $\mathrm{k}$-th repetition; $\mu$ is the overall mean; $\mathrm{B} / \mathrm{M}_{\mathrm{jk}}$ is the effect of the $\mathrm{k}$-th block within $\mathrm{j}$-th management; $G_{i}$ is the effect of the $i$-th genotype considered as fixed; $M_{j}$ is the effect of the $j$-th management considered as fixed; $\mathrm{GM}_{\mathrm{i} . \mathrm{i}}$ is the effect of $\mathrm{GxM}$ interaction considered as fixed; $\mathrm{e}_{\mathrm{ijk}}$ is the random error associated with $\mathrm{Y}_{\mathrm{ijk}}$ observation. Means were clustered by the Skott and Knott test (1974).

Genetics and Molecular Research 16 (2): gmr16029599 
Subsequently, the stability of the genotypes for each trait was estimated according to statistical ecovalence $\left(\mathrm{w}_{\mathrm{i}}\right)$ proposed by Wricke (1965) according to Equation 3.

$$
w_{i}=\mathrm{r} \sum_{j}\left(Y_{i j}-\bar{Y}_{i .}-\bar{Y}_{. j}+\bar{Y}_{. .}\right)
$$

(Equation 3)

where $r$ is the number of repetitions (blocks); is the mean of the i genotype at the $\mathrm{j}$ management; is the overall mean of the i-th genotype; is the overall mean of the $\mathrm{j}$-th management; is the overall mean of the trials. All analyses were performed using the Genes software (Cruz, 2013).

\section{RESULTS}

\section{Individual and joint analysis of variance}

Genotype effect was significant in all analyses of individual variance, regardless of the type of management and the evaluated trait (Table 1). The relationship between the largest and the smallest mean squared error was $2.87,1.38,1.37$, and 2.08 for the traits TNSSM, $\mathrm{TNF}, \mathrm{NCF}$, and fruit yield, respectively. The existence of a ratio lower than 7.0 indicates homogeneity of variances and make possible to perform joint analysis according to Banzatto and Kronka (2006).

Table 1. Summary of individual analysis of variance for the traits number of mites per $\mathrm{cm}^{2}$ (NTSSM), total number of fruits (TNF), number of commercial fruits (NCF), and fruit yield ( $t /$ ha) evaluated in 13 strawberry fruits grown in different managements.

\begin{tabular}{|c|c|c|c|c|}
\hline \multirow[t]{2}{*}{ Sources of variation } & \multirow[t]{2}{*}{ d.f. } & Open field & Low tunnel & High tunnel \\
\hline & & \multicolumn{3}{|c|}{${ }^{1}$ NTSSM } \\
\hline Blocks & 2 & 0.75 & 0.65 & 2.52 \\
\hline Genotypes & 12 & $4.81 *$ & $8.06^{*}$ & $6.18^{*}$ \\
\hline \multirow[t]{2}{*}{ Error } & 24 & 0.47 & 1.35 & 1.14 \\
\hline & & \multicolumn{3}{|c|}{${ }^{1} \mathrm{TNF}$} \\
\hline Blocks & 2 & 24.98 & 2.22 & 39.03 \\
\hline Genotypes & 12 & $63.83^{*}$ & $33.95 *$ & $47.82 *$ \\
\hline \multirow[t]{2}{*}{ Error } & 24 & 4.57 & 3.86 & 5.34 \\
\hline & & \multicolumn{3}{|c|}{${ }^{1} \mathrm{NCF}$} \\
\hline Blocks & 2 & 4.82 & 0.51 & 18.41 \\
\hline Genotypes & 12 & $27.61 *$ & $27.61 *$ & $50.07 *$ \\
\hline \multirow[t]{2}{*}{ Error } & 24 & 2.83 & 2.83 & 3.89 \\
\hline & & \multicolumn{3}{|c|}{ Fruit yield (t/ha) } \\
\hline Blocks & 2 & 69.06 & 8.24 & 252.86 \\
\hline Genotypes & 12 & $92.38^{*}$ & $149.49^{*}$ & $459.25^{*}$ \\
\hline Error & 24 & 20.89 & 20.03 & 41.73 \\
\hline
\end{tabular}

* Significant at $1 \%$ probability by the F-test; ${ }^{1}$ values for transformed data.

By joint analysis of variance, we verified that the effects of genotypes $(\mathrm{G})$, managements $(\mathrm{M})$ and $\mathrm{GxM}$ interaction were significant $(\mathrm{P}<0.01)$ for all evaluated characters (Table 2). The existence of significant GxM interaction indicates that there were differentiated agronomic responses as a function of the management used, hindering a recommendation in a generalized way. It is important to mention that the coefficient of variation estimates obtained were lower than $15 \%$ for all characters, indicating high experimental precision and credibility of the joint analysis.

Genetics and Molecular Research 16 (2): gmr16029599 
Table 2. Summary of joint analysis of variance for the traits number of mites per $\mathrm{cm}^{2}$ (NTSSM), total number of fruits (TNF), number of commercial fruits (NCF), and fruit yield (YIE, t/ha) evaluated in 13 strawberry fruits grown in different managements.

\begin{tabular}{l|c|c|c|c|c}
\hline Sources of variation & d.f. & NTSSM $^{1}$ & TNF $^{1}$ & NCF $^{1}$ & YIE \\
\hline Blocks/Management & 6 & 1.31 & 22.07 & 7.91 & 110.06 \\
\hline Genotypes (G) & 12 & $9.40^{*}$ & $89.82^{*}$ & $58.70^{*}$ & $418.13^{*}$ \\
\hline Managements (M) & 2 & $7.96^{*}$ & $707.17^{*}$ & $384.87^{*}$ & $1542.04^{*}$ \\
\hline GxM & 24 & $4.83^{*}$ & $27.89^{*}$ & $17.93^{*}$ & $141.49^{*}$ \\
\hline Residue & 72 & 0.99 & 4.59 & 3.29 & 27.55 \\
\hline Coefficient of variation (\%) & & 12.31 & 6.41 & 7.45 & 14.18 \\
\hline
\end{tabular}

*Significant at $1 \%$ probability by the F-test; ${ }^{1}$ values for transformed data.

\section{Means comparison}

NTSSM observed in the strawberry genotypes as a function of the different treatments used is shown in Table 3. The evaluated management systems influenced the incidence of TSSM differently in each genotype. The infestation of TSSM in the genotypes Albion, Aromas, Dover, Seascape, and Toyonoka was lower under open-field management. In general, lowtunnel management provided a higher incidence of TSSM in all genotypes, with the exception of Toyonoka. The Toyonoka genotype showed the lowest incidence of TSSM at open field and low tunnel, but under high tunnel it was the genotype that presented the highest infestation. The genotypes Aromas, Camarosa, and Festival presented the lowest incidence of TSSM in all the evaluated managements (Table 3 ).

\begin{tabular}{|c|c|c|c|}
\hline Genotype & Open field & Low tunnel & High tunnel \\
\hline Albion & $8.37^{\mathrm{laB}}$ & $9.93^{\mathrm{bA}}$ & $7.30^{\mathrm{bB}}$ \\
\hline Aleluia & $7.90^{\mathrm{aA}}$ & $6.80^{\mathrm{cA}}$ & $8.17^{\mathrm{bA}}$ \\
\hline Aromas & $6.67^{\mathrm{bB}}$ & $9.00^{\mathrm{bA}}$ & $7.07^{\mathrm{bB}}$ \\
\hline Camarosa & $5.80^{\mathrm{bA}}$ & $6.67^{\mathrm{cA}}$ & $6.73^{\mathrm{bA}}$ \\
\hline Camino Real & $9.03^{\mathrm{aA}}$ & $8.77^{\mathrm{bA}}$ & $7.90^{\mathrm{bA}}$ \\
\hline Campinas & $8.87^{\mathrm{aA}}$ & $7.97^{\mathrm{cA}}$ & $7.97^{\mathrm{bA}}$ \\
\hline Diamante & $8.03^{\mathrm{aA}}$ & $7.27^{\mathrm{AA}}$ & $6.57^{\mathrm{bA}}$ \\
\hline Dover & $8.37^{\mathrm{aB}}$ & $12.27^{\mathrm{aA}}$ & $10.87^{\mathrm{aA}}$ \\
\hline Festival & $7.10^{\mathrm{bA}}$ & $8.90^{\mathrm{bA}}$ & $7.43^{\mathrm{bA}}$ \\
\hline Seascape & $7.53^{\mathrm{aB}}$ & $9.67^{\mathrm{bA}}$ & $8.00^{\mathrm{bB}}$ \\
\hline Toyonoka & $5.40^{\mathrm{bB}}$ & $7.13^{\mathrm{cB}}$ & $10.60^{\mathrm{aA}}$ \\
\hline Tudla & $9.83^{\mathrm{aA}}$ & $10.10^{\mathrm{bA}}$ & $7.33^{\mathrm{bB}}$ \\
\hline Ventana & $8.20^{\mathrm{aA}}$ & $7.17^{\mathrm{cA}}$ & $5.93^{\mathrm{bB}}$ \\
\hline
\end{tabular}

${ }^{1}$ Values transformed via $\sqrt{ }(x+1 / 2)$. Means followed by lower case letters in the same column and the same capital letters on the same line do not differ by the Skott and Knott (1974) test at 5\% probability.

Table 4 shows the TNF trait evaluated in the strawberry genotypes according to each management. In general, low-tunnel and high-tunnel management provided the highest means for genotypes when compared to open-field management. The genotype Campinas showed the highest means of TNF under open field and low tunnel. Camarosa and Festival genotypes presented the highest means of TNF under protected environment (high and low tunnel). It is important to note that although a genotype with the highest means under all treatments was not found, the Festival genotype presented satisfactory means of TNF under open field.

Genetics and Molecular Research 16 (2): gmr16029599 
Table 4. Mean values for total number of fruits evaluated in 13 strawberry genotypes grown in different managements.

\begin{tabular}{l|c|c|c}
\hline Genotype & Open field & Low tunnel & High tunnel \\
\hline Albion & $24.10^{\mathrm{ddB}}$ & $29.83^{\mathrm{dA}}$ & $33.83^{\mathrm{Da}}$ \\
\hline Aleluia & $25.77^{\mathrm{dB}}$ & $32.90^{\mathrm{cA}}$ & $39.47^{\mathrm{Aa}}$ \\
\hline Aromas & $33.23^{\mathrm{bB}}$ & $33.87^{\mathrm{cB}}$ & $41.80^{\mathrm{Aa}}$ \\
\hline Camarosa & $26.00^{\mathrm{dB}}$ & $38.10^{\mathrm{aA}}$ & $32.80^{\mathrm{Da}}$ \\
\hline Camino Real & $24.00^{\mathrm{dB}}$ & $30.07^{\mathrm{dA}}$ & $30.80^{\mathrm{Da}}$ \\
\hline Campinas & $39.50^{\mathrm{aA}}$ & $39.20^{\mathrm{aA}}$ & $35.90^{\mathrm{Ca}}$ \\
\hline Diamante & $24.37^{\mathrm{dB}}$ & $30.43^{\mathrm{dA}}$ & $42.67^{\mathrm{Aa}}$ \\
\hline Dover & $28.90^{\mathrm{cB}}$ & $35.67^{\mathrm{bA}}$ & $38.00^{\mathrm{Ba}}$ \\
\hline Festival & $32.97^{\mathrm{bB}}$ & $40.23^{\mathrm{aA}}$ & $39.03^{\mathrm{Ba}}$ \\
\hline Seascape & $30.23^{\mathrm{bB}}$ & $35.83^{\mathrm{bA}}$ & $36.60^{\mathrm{Ca}}$ \\
\hline Toyonoka & $28.87^{\mathrm{CB}}$ & $36.43^{\mathrm{bA}}$ & $33.33^{\mathrm{Da}}$ \\
\hline Tudla & $30.37^{\mathrm{bB}}$ & $33.97^{\mathrm{cA}}$ & $35.30^{\mathrm{bA}}$ \\
\hline Ventana & $24.60^{\mathrm{dB}}$ & & \\
\hline
\end{tabular}

${ }^{1}$ Values transformed via $\sqrt{ }(x+1 / 2)$. Means followed by lower case letters in the same column and the same capital letters on the same line do not differ by the Skott and Knott (1974) test at 5\% probability.

Similar to that observed for the TNF trait, the low- and high-tunnel managements provided the highest means of NCF for all genotypes (Table 5). Open-field management did not differ in protected environments only for NCF from the genotypes Campinas, Dover, Seascape, Toyonoka, and Tudla. Festival presented the highest means of NCF in all managements. However, other specific and positive interactions should be highlighted as among the Aromas and Campinas genotypes with open-field management, Camarosa with low-tunnel management and Aleluia with high-tunnel management.

Table 5. Mean values for number of commercial fruits evaluated in 13 strawberry genotypes grown in different managements.

\begin{tabular}{l|c|c|c}
\hline Genotype & Open field & Low tunnel & High tunnel \\
\hline Albion & $18.70^{\mathrm{lcB}}$ & $23.83^{\mathrm{cA}}$ & $27.57^{\mathrm{Ba}}$ \\
\hline Aleluia & $19.57^{\mathrm{bB}}$ & $27.10^{\mathrm{bA}}$ & $33.23^{\mathrm{Aa}}$ \\
\hline Aromas & $26.60^{\mathrm{aB}}$ & $26.73^{\mathrm{bA}}$ & $28.73^{\mathrm{Ba}}$ \\
\hline Camarosa & $20.20^{\mathrm{bB}}$ & $29.23^{\mathrm{aA}}$ & $24.97^{\mathrm{Ca}}$ \\
\hline Camino Real & $16.20^{\mathrm{cB}}$ & $24.33^{\mathrm{cA}}$ & $22.33^{\mathrm{Da}}$ \\
\hline Campinas & $24.63^{\mathrm{aA}}$ & $23.37^{\mathrm{cA}}$ & $23.87^{\mathrm{Ca}}$ \\
\hline Diamante & $18.77^{\mathrm{cB}}$ & $25.10^{\mathrm{cA}}$ & $33.40^{\mathrm{Aa}}$ \\
\hline Dover & $18.80^{\mathrm{cA}}$ & $22.77^{\mathrm{cA}}$ & $25.07^{\mathrm{Ca}}$ \\
\hline Festival & $24.70^{\mathrm{aB}}$ & $30.97^{\mathrm{aA}}$ & $22.60^{\mathrm{Da}}$ \\
\hline Seascape & $21.97^{\mathrm{bA}}$ & $24.80^{\mathrm{cA}}$ & $25.93^{\mathrm{Ca}}$ \\
\hline Toyonoka & $20.80^{\mathrm{bA}}$ & $25.40^{\mathrm{cA}}$ & $25.57^{\mathrm{Ca}}$ \\
\hline Tudla & $20.87^{\mathrm{bA}}$ & $24.60^{\mathrm{cA}}$ & $27.30^{\mathrm{bA}}$ \\
\hline Ventana & $17.63^{\mathrm{cB}}$ & & \\
\hline
\end{tabular}

${ }^{1}$ Values transformed via $\sqrt{ }(x+1 / 2)$. Means followed by lower case letters in the same column and the same capital letters on the same line do not differ by the Skott and Knott (1974) test at 5\% probability.

The fruit yield of strawberry genotypes according to the different managements is shown in Table 6. As in the other yield components (TNF and NCF), protected environments provided to all genotypes increased yield compared to the open-field management. The genotype Aleluia obtained the highest means, regardless of the management used. However, the Festival genotype deserves to be highlighted once again, as it presented the highest means under open-field and low-tunnel managements and obtained satisfactory yield under hightunnel management. 
Table 6. Mean values for fruit yield ( $\mathrm{t} / \mathrm{ha}$ ) evaluated in 13 strawberry genotypes grown in different managements.

\begin{tabular}{l|c|c|c}
\hline Genotype & Open field & Low tunnel & High tunnel \\
\hline Albion & $26.77^{\mathrm{bB}}$ & $35.23^{\mathrm{bA}}$ & $41.73^{\mathrm{Ca}}$ \\
\hline Aleluia & $32.27^{\mathrm{aB}}$ & $45.07^{\mathrm{aB}}$ & $45.87^{\mathrm{Aa}}$ \\
\hline Aromas & $40.40^{\mathrm{aA}}$ & $36.63^{\mathrm{bA}}$ & $49.63^{\mathrm{Ba}}$ \\
\hline Camarosa & $28.47^{\mathrm{bB}}$ & $49.83^{\mathrm{aA}}$ & $42.73^{\mathrm{Ca}}$ \\
\hline Camino Real & $24.97^{\mathrm{bB}}$ & $42.20^{\mathrm{aA}}$ & $27.00^{\mathrm{Da}}$ \\
\hline Campinas & $35.07^{\mathrm{aA}}$ & $32.30^{\mathrm{bA}}$ & $24.33^{\mathrm{Ca}}$ \\
\hline Diamante & $28.97^{\mathrm{bB}}$ & $40.27^{\mathrm{bA}}$ & $53.97^{\mathrm{Ba}}$ \\
\hline Dover & $20.83^{\mathrm{bA}}$ & $27.57^{\mathrm{bA}}$ & $36.60^{\mathrm{Ca}}$ \\
\hline Festival & $37.33^{\mathrm{aB}}$ & $49.90^{\mathrm{aA}}$ & $31.03^{\mathrm{Da}}$ \\
\hline Seascape & $31.33^{\mathrm{aA}}$ & $37.93^{\mathrm{bA}}$ & $38.93^{\mathrm{Ca}}$ \\
\hline Toyonoka & $25.80^{\mathrm{bA}}$ & $36.20^{\mathrm{bA}}$ & $40.77^{\mathrm{Ca}}$ \\
\hline Tudla & $31.40^{\mathrm{aA}}$ & $34.07^{\mathrm{bA}}$ & $48.50^{\mathrm{aA}}$ \\
\hline Ventana & $24.30^{\mathrm{bB}}$ & & \\
\hline
\end{tabular}

${ }^{1}$ Values transformed via $\sqrt{ }(x+1 / 2)$. Means followed by lower case letters in the same column and the same capital letters on the same line do not differ by the Skott and Knott (1974) test at 5\% probability.

\section{Stability of genotypes for the evaluated traits}

We identified few strawberry genotypes that presented satisfactory agronomic performance in all the evaluated managements. These results were expected due to the presence of a significant GxM interaction. For the fruit yield, main trait of agronomic and economic importance, Aleluia was superior to the others in all the managements. However, it is necessary to investigate the contribution of these genotypes to the GxM interaction before its widespread recommendation. Therefore, the Wricke method (1965) was applied as an auxiliary tool to select the genotypes that present greater phenotypic stability over the different evaluated managements (Table 7).

Table 7. Estimates of ecovalence (\%) by Wricke method (1965) for the traits number of mites per $\mathrm{cm}^{2}$ (NTSSM), total number of fruits (TNF), number of commercial fruits (NCF), and fruit yield (YIE, t/ha) evaluated in 13 strawberry genotypes grown in different managements.

\begin{tabular}{l|c|c|c|c}
\hline Genotype & NTSSM & TNF & NCF & YIE \\
\hline Albion & 4.64 & 0.88 & 4.48 & 1.00 \\
\hline Aleluia & 7.06 & 19.19 & 22.98 & 41.46 \\
\hline Aromas & 3.31 & 6.72 & 8.75 & 8.17 \\
\hline Camarosa & 1.24 & 14.41 & 5.77 & 6.68 \\
\hline Camino Real & 2.24 & 0.11 & 4.29 & 2.75 \\
\hline Campinas & 3.80 & 48.08 & 25.05 & 17.70 \\
\hline Diamante & 4.16 & 0.94 & 7.07 & 1.86 \\
\hline Dover & 13.74 & 0.83 & 3.10 & 1.08 \\
\hline Festival & 1.35 & 0.56 & 2.83 & \\
\hline Seascape & 2.38 & 0.06 & 6.43 & \\
\hline Toyonoka & 38.88 & 0.94 & 0.64 & 2.70 \\
\hline Tudla & 9.41 & 1.53 & 7.32 & \\
\hline Ventana & 7.80 & 5.76 & & 2.29 \\
\hline
\end{tabular}

The genotypes Festival, Seascape, Camino Real, Albion, and Diamante presented the lowest contribution estimates to the GxM interaction for all evaluated traits. Therefore, these genotypes were those that had greater phenotypic stability throughout the different treatments used. However, the simple evaluation of phenotypic stability is not sufficient for the accurate recommendation of the best genotypes. For example, the most productive genotype in all

Genetics and Molecular Research 16 (2): gmr16029599 
treatments (Aleluia) was the one that most contributed to the GxM interaction. It is necessary to associate these observations with the agronomic performance of these genotypes in the different managements. Thus, the genotype most suitable for growing in different management was the Festival genotype, since it presented less susceptibility to TSSM, high fruit yield, and phenotypic stability.

\section{DISCUSSION}

Genetic variability detected in the individual analysis is important because it shows that it is possible to select genotypes with lower incidence of TSSM, higher TNF, NCF, and fruit yield. However, the joint analysis revealed a significant effect of the interaction between GxM, corroborating the results observed by Costa et al. (2015). Therefore, it is necessary to employ analyses that can detect the phenotypic stability of these genotypes throughout the management used, which allows us to make a more reliable recommendation.

The coefficient of variation estimates observed in joint analysis are similar to those reported in other strawberry studies (Radmann et al., 2006; Moncada et al., 2008; Resende et al., 2010; Randin et al., 2011; Costa et al., 2015, 2016). According to Cruz et al. (2012), coefficient of variation estimates lower than $20 \%$ indicate high experimental precision for quantitative traits, such as those evaluated in this study.

Using protected cropping in strawberry cultivation has been an increasingly frequent practice, but its effect on the incidence of TSSM in strawberry has not yet been evaluated. High tunnel-protected system has provided satisfactory agronomic performance for growing conditions of the State of Espírito Santo, Brazil, possibly due to the lower interference in the microclimate (Balbino et al., 2006; Costa et al., 2015). However, TSSM infestation levels under protected cropping system (high and low tunnel) were higher than the open-field production system for most genotypes.

However, the use of protected environment in the strawberry crop has the advantage of discouraging disease incidence. This is due to the lower accumulation of water on the leaves, which reduces the use of fungicides and enables strawberry production with greater food safety, greater plant longevity and yield (Balbino et al., 2006). An alternative to attenuate the effects of protected environments on the incidence of TSSM is to find genotypes with greater tolerance to this pest. Among the evaluated genotypes, Camarosa and Festival presented the lowest averages for the NTSSM in all managements. In addition, these genotypes have high phenotypic stability in relation to this trait, which makes it possible to recommend its use in breeding programs aimed at strawberry resistance to TSSM.

The greater T. urticae infestation can be explained by the lower presence of glandular trichomes, which present negative correlation with the dispersion capacity of the T. urticae in strawberry (Figueiredo et al., 2010). Strawberry has two types of trichomes: the first unicellular, long and thin; the second multicellular, smaller and with distinct cell, rounded at the tip. Only the second is considered as a potential resistance factor due to the presence of oxidative enzymes that act on the extravasation of phenolic compounds by the damages caused by TSSM (Steinite and Ievinsh, 2003). The presence of glandular and non-glandular trichomes, as well as its density, in addition to reducing the T. urticae survival, also limits its displacement, mainly in young forms due to it be mechanical obstacle and exudation of adhesive substances, with decreased oviposition (Luczynski et al., 1990).

Using resistant genotypes is the main control method within integrated pest

Genetics and Molecular Research 16 (2): gmr16029599 
management, since it associates lower costs for producers and less environmental impact (Marques-Francovig et al., 2014). Therefore, the knowledge of the behavior of several genotypes to the T. urticae attack is necessary for breeding programs that aim to develop cultivars tolerant to biotic stresses such as TSSM. However, for a genotype to be used as a genitor in breeding programs, it is necessary that besides the tolerance to the TSSM this genotype has a series of favorable traits, among them high TNF, NCF, and fruit yield.

Wricke method (1965) used in this study is recommended for research with smaller number of environments (Cruz et al., 2012) and its statistics (ecovalence) is estimated based on joint analysis of variance. This method identified the contribution from each genotype to the GxM interaction, allowing us to recommend those with greater phenotypic stability in relation to the traits of interest. By associating the results of phenotypic stability with the incidence of TSSM and the agronomic performance of the genotypes along the management, it is possible to verify that the Festival genotype meets all the desirable traits for a recommendation of a generalized form (independent of the management).

However, it is suggested for future studies that the genetic diversity between these genotypes should be evaluated in order to guide the crosses that provide promising segregating populations in strawberry-breeding programs. For example, the Festival genotype, identified as ideal in this study, can be used to compose blocks of crosses with other more productive genotypes such as the Aleluia genotype.

\section{Conflicts of interest}

The authors declare no conflict of interest.

\section{ACKNOWLEDGMENTS}

We are thankful to CAPES (Coordenação de Aperfeiçoamento de Pessoal de Ensino Superior) and CNPq (Conselho Nacional de Desenvolvimento Científico e Tecnológico).

\section{REFERENCES}

Antunes LEC and Peres NA (2013). Strawberry Production in Brazil and South America. Int. J. Fruit Sci. 13: 156-161. http://dx.doi.org/10.1080/15538362.2012.698147

Balbino JMS, Athayde MO, Teixeira CP, Costa H, et al. (2006). Tecnologias para produção de mudas e cultivo comercial de morango. In: Tecnologias para produção, colheita e pós-colheita de morangueiro (Balbino JMS, ed.). 2nd edn. Incaper, Vitória.

Banzatto DA and Kronka SN (2006). Experimentação agrícola. FUNEP, Jaboticabal.

Bernardi D, Botton M, Nava DE and Zawadneak MAC (2015). Guia para identificação e monitoramento de pragas e seus inimigos naturais em morangueiro. Embrapa, Brasília.

Costa AF, Leal NR, Ventura JA, Gonçalves LSA, et al. (2015). Adaptability and stability of strawberry cultivars using a mixed model. Acta Sci. Agron. 37: 435-440 http://dx.doi.org/10.4025/actasciagron.v37i4.18251.

Costa AF, Teodoro PE, Bhering LL, Leal NR, et al. (2016). Biplot analysis of strawberry genotypes recommended for the State of Espírito Santo. Genet. Mol. Res. 15: gmr.15038919. http://dx.doi.org/10.4238/gmr.15038919

Cruz CD (2013). Genes: a software package for analysis in experimental statistics and quantitative genetics. Acta Sci. Agron. 35: 271-276 http://dx.doi.org/10.4025/actasciagron.v35i3.21251.

Cruz CD, Carneiro PCS and Regazzi AJ (2012). Modelos biométricos aplicados ao melhoramento genético. 3rd edn. Editora UFV, Viçosa.

Fadini MAM, Pallinz A and Venzon M (2004). Controle de ácaros em sistema de produção integrada de morango. Cienc. Rural 34: 1271-1277. http://dx.doi.org/10.1590/S0103-84782004000400053

Genetics and Molecular Research 16 (2): gmr16029599 
Figueiredo AST, Resende JTV, Dias DM, Gonçalves APS, et al. (2010). Repelência de cultivares de morangueiro ao ácaro rajado, mediada por tricomas foliares. Hortic. Bras. 28: S603-S609.

Fornazier MJ and Pratissoli D (2006). Pragas do morangueiro. In: Tecnologias para produção, colheita e pós-colheita de morangueiro (Balbino JMS, ed.). 2nd edn. Incaper, Vitória.

Greco NM, Pereyra PC and Guillade A (2005). Host-plant acceptance and performance of Tetranychus urticae (Acari: Tetranychidae). J. Appl. Entomol. 130: 32-36. http://dx.doi.org/10.1111/j.1439-0418.2005.01018.x

Iwassaki LA, Sato ME, Calegario FF, Poletti M, et al. (2015). Comparison of conventional and integrated programs for control of Tetranychus urticae (Acari: Tetranychidae). Exp. Appl. Acarol. 65: 205-217. http://dx.doi.org/10.1007/ s10493-014-9853-4

Lourenção AL, Moraes GJ, Passos FA, Ambrosano GMB, et al. (2000). Resistência de morangueiros a Tetranychus urticae Koch (Acari: Tetranychidae). Anais Soc. Entomol. Brasil. 29: 339-346. http://dx.doi.org/10.1590/S0301$\underline{80592000000200016}$

Luczynski A, Isman MB, Raworth DA and Chan CK (1990). Chemical and morphological factors of resistance against the two spotted spider mite in beach strawberry. J. Econ. Ent. 83: 564-569. http://dx.doi.org/10.1093/jee/83.2.564

Marques-Francovig CR, Mikami AY, Dutra V, Carvalho MG, et al. (2014). Fertilização orgânica e inseticidas botânicos para o controle do ácaro rajado em morango. Cienc. Rural 44: 1908-1914. http://dx.doi.org/10.1590/0103$\underline{8478 \mathrm{cr} 20131575}$

Maruyama WI, Toscano LC, Boiça-Júnior AL and Barbosa JC (2002). Resistência de genótipos de tomateiro ao ácaro rajado. Hortic. Bras. 20: 480-484. http://dx.doi.org/10.1590/S0102-05362002000300017

Moncada A, Miceli A and D'Anna F (2008). Evaluation of strawberry cultivars in soilless cultivation in Sicily. Acta Hortic. 801: 1121-1128 http://dx.doi.org/10.17660/ActaHortic.2008.801.135.

Oliveira RP, Scivittaro WB and Finkenauer D (2008). Produção de MORANGUEIRO da cv. Camino Real em sistema de túnel. Rev. Bras. Frutic. 30: 681-684. http://dx.doi.org/10.1590/S0100-29452008000300020

Ozdemir E (2003). Early production of strawberry cultivars grown under plastic houses on sand dunes. Small. Fr. Rev. 2: 81-86.

Ozdemir E and Gunduz K (2004). Comparison of bag raised bed treatments for strawberry production under unheated greenhouse conditions. J. Am. Pomol. Soc. 58: 118-122.

Radmann EB, Bianchi VJ, Oliveira RP and Fachinello JC (2006). Caracterização e diversidade genética de cultivares de morangueiro. Hortic. Bras. 24: 84-87 http://dx.doi.org/10.1590/S0102-05362006000100017.

Randin B, Lisboa BB, Witter S, Barni V, et al. (2011). Desempenho de quatro cultivares de morangueiro em duas regiões ecoclimáticas do Rio Grande do Sul. Hortic. Bras. 29:287-291 http://dx.doi.org/10.1590/S0102-05362011000300005.

Resende JTV, Morales RGF, Faria MV, Rissini ALL, et al. (2010). Produtividade e teor de sólidos solúveis de frutos de cultivares de morangueiro em ambiente protegido. Hortic. Bras. 28: 185-189 http://dx.doi.org/10.1590/S0102$\underline{05362010000200008 .}$.

Sato ME, Silva M, Gonçalves LR, Souza-Filho MF, et al. (2002). Toxicidade diferencial de agroquímicos a Neoseiulus californicus (McGregor) (Acari: Phytoseiidae) e Tetranychus urticae Koch (Acari: Tetranychidae) em morangueiro. Neot. Ent. 31: 449-456.

Scott A and Knott M (1974). Cluster-analysis method for grouping means in analysis of variance. Biometrics 30: 507-512.

Steinite I and Ievinsh G (2003). Possible role of thricomes in resistance of strawberry cultivars against spider mite. Acta Univ. Lat. 662: 59-65.

Svensson B (2006). Organic strawberries in the tunnels with control of powdery mildew and mites. Finland: NJF seminar.

Tazzo IF, Fagherazzi AF, Lerin S, Kretzschmar AA, et al. (2015). Exigência térmica de duas seleções e quatro cultivares de morangueiro cultivado no planalto catarinense. Rev. Bras. Frutic. 37: 550-558. http://dx.doi.org/10.1590/01002945-097/14

Wricke G (1965). Zur Berechnung der Ökovalenz bei Sommerweizen und Hafer. Pflanzenzuchtung 52: 127-138.

Xiao CL, Chandler CK, Price JF, Duval JR, et al. (2001). Comparison of epidemics of Botrytis fruit rot and powdery mildew of strawberry in large plastic tunnel and field production systems. Plant Dis. 85: 901-909. http://dx.doi. org/10.1094/PDIS.2001.85.8.901

Genetics and Molecular Research 16 (2): gmr16029599 